\title{
Social-ecological innovation: adaptive responses to urban environmental conditions
}

\author{
Matthew Dennis $^{1} \cdot$ Richard P. Armitage ${ }^{1} \cdot$ Philip James $^{1}$
}

Published online: 1 April 2016

(C) The Author(s) 2016. This article is published with open access at Springerlink.com

\begin{abstract}
Novel approaches to natural resource management, particularly those which promote stakeholder participation, have been put forward as fundamental ingredients for establishing resilient, polycentric forms of environmental governance. This is nowhere more pertinent than in the case of the complex adaptive systems associated with urban areas. Decentralisation of urban green space management has been posited as an element thereof which, according to resilience thinking, should contribute to the adaptive capacity of cities and the ecosystem services upon which they rely. Implicit in this move towards increased adaptive capacity is the ability to manage through innovation. Although the importance of innovation towards system adaptability has been acknowledged, little work has thus far been carried out which demonstrates that innovative use of urban green space represents a form of adaptive response to environmental conditions. The current paper reports on research which maps examples of organised social-ecological innovation (OSEI) in an urban study area and evaluates them as adaptive responses to local environmental conditions which may contribute to system resilience. The results present OSEI as a coherent body of responses to local social and environmental deprivation, exhibiting diversity and adaptability according to individual contexts. The study therefore provides evidence for the importance of local stakeholder-led innovation as in the building of adaptive capacity in urban social-ecological systems.
\end{abstract}

Keywords Urban · Social-ecological systems · Adaptive capacity · Resilience · Environmental governance

\section{Introduction}

The role of stakeholder involvement in natural resource management has been widely promoted in international environmental policy. The Ecosystem Approach calls for the appropriate

Matthew Dennis

m.dennis@salford.ac.uk

1 School of Environment and Life Sciences, College of Science and Technology, University of Salford, Room 203 Cockroft Building, The Crescent, Salford M5 4WT, UK 
decentralisation of ecosystem management (Principle 2: CBD 2004) and the Millennium Ecosystem Assessment similarly asserts the need for stakeholder-led processes with regards to decision-making on local environmental stewardship (MEA 2005). More recently, in the UK National Ecosystem Assessment (UK NEA 2011), there is an acknowledgement of the role of individuals and groups as environmental actors. The recommendations of the UK NEA Synthesis Report (2011)) called for increased promotion of stakeholder participation, collaboration between social-ecological actors, and the provision of environment-based education. Such an approach is particularly relevant in urban areas, home to the majority of world's population (United Nations, 2007), where anthropogenic influences on environmental processes are often far-reaching (Kalnay and Cai 2003; Verburg et al. 2010; Lambin and Meyfroidt 2011). The urban environment offers some of the greatest challenges to but, also, some of the greatest opportunities for resilient ecosystem services, through innovative and adaptive resource management and the decentralisation of environmental governance (CBD 2012).

These recommendations are founded on an increasing body of research in the fields of social-ecological systems and resilience thinking. (e.g. Gunderson 2000; Gunderson and Holling 2002; Walker et al. 2004; Walker et al. 2006; Carpenter and Brock 2008; Biggs et al. 2010). The value of community participation in natural resource management towards the establishment of polycentric governance has been asserted as a major ingredient in the adaptive capacity of social-ecological systems (Walker et al. 2002; Biggs et al. 2010; Gunderson and Berkley 2015) enhancing both human and environmental well-being (Hynes and Howe 2004; Pudup 2008; Dennis and James 2016). Such measures should contribute to the flexible, adaptive management of ecosystem services across physical and temporal scales (Biggs et al. 2012). Nowhere is such an adaptive approach to ecosystems management more pertinent than in today's most modified landscape, the centre of human knowledge and decision-making, and now home to most of the world's "individuals": the urban environment. Many of today's post-industrial cities have been subject to both socio-economic disinvestment (Krasny and Tidball 2015) and ecological decline (MEA 2005; UK NEA 2011). Such trends consist of slow variables (Gunderson and Holling 2002) which contribute to social and ecological deprivation in city landscapes, eventually culminating in "broken places" within the urban environment (Krasny and Tidball 2015). Actors within urban areas, are therefore presented with significant challenges and opportunities for the creation of new innovative, collaborative approaches to natural resource management in human-dominated ecosystems.

Studies have shown that interaction with urban nature has benefits for city-dwellers in the form of physical (de Vries et al. 2003), therapeutic (Fuller et al. 2007), educational (Larsen et al. 2010) and social (Pudup 2008) gains. Furthermore, the relationship has been shown to be reciprocal with increasing biodiversity associated with user participation in communallymanaged spaces (Dennis and James 2016).

Community-led management of urban green spaces involves a degree of stakeholder participation which may contribute to the decentralisation of natural resource governance and the generation of vital urban ecosystem services (Barthel et al. 2013). The presence of such examples of community appropriation and collaborative management of local green space constitutes a form of organised social-ecological innovation (OSEI). Such innovation may appear in a variety of forms and contexts. Informal management of communal green spaces by urban residents has been posited as one social-ecological measure that may be a key element in the building of more resilient cities (Ernstson et al. 2008; Krasny and Tidball 2009; Colding and Barthel 2013). Assertions in the scientific literature maintain that the devolution of highly centralised approaches to natural resource management to more decentralised forms 
of governance, with a focus on collaborative networks, ought to be beneficial (e.g. Andersson et al. 2007; Biggs et al. 2010). The hallmark of such governance should be an emphasis on building adaptive capacity and response diversity in order to enable urban social-ecological systems to withstand internal and external fluctuations and ensure the continued production of vital ecosystem services into the future (Gunderson 2000; Biggs et al. 2012). To this end, innovation is of vital importance for system resilience through the emergence of adaptive responses to changing social-ecological conditions (Olsson et al. 2006). The ability to adapt accordingly is one measure by which elements within systems, such as social-ecological actors in urban areas, may be assessed as contributing positively to overall system resilience.

Ethnographic investigations of the phenomenon of social-ecological innovation have gleaned insights into the motives and views of social-ecological actors (Kingsley et al. 2009; Corrigan 2011; Rosol 2012; Green and Phillips 2013), and social network analyses have been presented which highlight the importance of social ties (Ernstson et al. 2010) and organisational hierarchies (Ernstson et al. 2008) in the adaptive co-management of ecosystem services. Notwithstanding the promotion of polycentric, stakeholder led ecosystem management at research (Gunderson and Holling 2002; Biggs et al. 2012) and policy (CBD 2004; UK NEA 2011) levels, the majority of the work cited here has adopted a conceptual, theoretical or purely qualitative stance in its treatment of the subject. Such work therefore lacks a detailed, empirically based quantitative evaluation of the contribution of urban-innovative elements towards adaptive capacity to environmental stressors. Examples of civic ecological responses to disturbing environmental events have been presented in the literature (Tidball et al. 2010; Krasny and Tidball 2012, 2015), but such work has failed to map and evaluate social-ecological innovation as a coherent phenomenon within social-ecological systems. A clearer understanding of the environmental contexts which accompany such innovation is therefore timely.

Without a spatial evaluation of the occurrence of social-ecological innovation in the urban landscape it is not possible to confirm such innovation as being contributory towards adaptive capacity in urban social-ecological systems. Studies have been carried out which describe stakeholder-led management of natural resources as responsive to local social and ecological stressors (Rodima-Taylor et al. 2012). However, in order to assert social-ecological intervention by communities as truly adaptive, it must demonstrate responsivity according to social-ecological contexts (Olsson and Galaz 2012), occupying social-ecological niches in the urban landscape. Although previous work has offered examples of a range of social-ecologically innovative approaches to urban green space use and management (Krasny and Tidball 2012, 2015) there has not been a concerted effort to characterise discrete types of social-ecological innovation within cityscapes, nor to test their contribution to adaptive capacity by evaluating their occurrence relative to local environmental conditions. Doing so would allow for a greater appreciation of such innovation in terms of its responsive nature, the diversity of responsivity exhibited at the landscape scale, and the adaptability which it thereby exhibits relative to unique social-ecological contexts.

The authors explored the range of approaches presented by examples of organised socialecological innovation (OSEI), and their environmental contexts, in a north-west UK conurbation in order to evaluate the degree to which the phenomenon demonstrated adaptive capacity relative to its surroundings. In order to be considered as contributing to adaptive capacity, OSEI in the study area was assessed on three criteria according to recommendations from the literature. Namely, the innovation should: a) constitute a coherent, intelligent response to local conditions (Folke 2006; Gunderson 2010; Barthel et al. 2013), b) exhibit a diversity of responses to such conditions (Folke et al. 2005; Elmqvist et al. 2003; Walker et al. 2006) 
and, c) demonstrate adaptability to unique social-ecological contexts (Folke et al. 2002; Brooks and Adger 2004).

\section{Methods}

Spatial analyses were carried out on the locations of examples of organised social-ecological innovation which were identified using a snowball sampling method (after Goodman 1961) in the adjoining metropolitan areas of Manchester, Trafford and Salford, UK. The Manchester area, as one of the world's first centres of industry (Kidd 2006) has a long history of socialecological activism associated with urbanisation (AfSL n.d.; Ritvo 2010; Dennis and James 2016) and, as such, provided a suitable study area for a spatial investigation into socialecological innovation.

$\mathrm{XY}$ point data for each site were then entered into a geographic information system. Localities in which OSEIs were present were examined relative to non-OSEI locations, and through pair-wise comparisons with other types of OSEI, across social and land-cover variables in order to establish the salient environmental contexts of OSEI occurrence. All spatial analyses were carried out in ArcGIS.9.

\section{Area deprivation characteristics}

Data pertaining to UK land-cover were obtained from the UK's Office for National Statistics' Generalised Land Use Database (2005). The database classifies areas at a range of geographical units into nine discrete built and green land-cover types. Data at the lower super output area (LSOA: ONS 2001) level were employed in the characterisation of the study area. Lower super output areas comprise the smallest geographical unit used by the UK government Office for National Statistics to report small area statistics and have populations of between 1000 and 3000 persons, and between 400 and 1200 households (ONS 2015). The Generalised Land Use Database was used to characterise the study area by calculating the percentage cover by built land-use types (domestic and non-domestic buildings, roads, rail and other hardstanding surfaces). The resulting variable, as a measure of surface sealing, was used as a proxy for local ecological deprivation. Surface sealing was chosen as an established measure adopted in urban environmental planning and research. The concept is widely adopted in green infrastructure planning tools to reflect ecological deprivation. The Berlin Biotope Area Factor (Becker and Mohren 1990) and subsequent versions adopted by environmental authorities in Malmö, Sweden (Kruuse 2011) and Southampton, UK (Southampton City Council 2013) are founded on the concept of ecological effectiveness. This concept is essentially derived from the proportion of sealed, semi-sealed and vegetated elements which cover a given site. Likewise, measures of surface sealing as an indication of environmental deprivation experienced by urban residents have been adopted in research exploring quality of life and wellbeing (Lo 1997) and environmental performance in urban areas (Pauleit and Duhme 2000; Breuste et al. 2013). The UK NEA (2011) highlighted the decline, over recent years, in the provision of green space in urban areas and the resulting degradation of ecosystem services vital to human well-being in cities. Mapping the extent of localised surface sealing as a measure of green space deprivation in the study area therefore provided a variable with which to assess the occurrence of OSEI as a response to environmental stressors. Information 
concerning the spatial dimensions of buildings was not taken into consideration as the aim of the study was to explore social-ecological innovation as a response to levels of provision of green space. In this sense, the shape or height of buildings was not a relevant consideration, nor were other green indices such as the Normalised Difference Vegetation Index which are sensitive to density of vegetation and canopy extent (NASA 2015) and, therefore, not accurately indicative of areas of recreational, public or domestic green space.

In order to explore the relationship between local levels of social deprivation and the occurrence of types of OSEI, secondary data were taken from the 2010 English Index of Multiple Deprivation (DCLG 2010). The IMD is built from thirty-eight separate indicators derived from UK census data across seven distinct domains relating to discrete forms of social deprivation. The seven domains are: Income Deprivation, Employment Deprivation, Health Deprivation and Disability, Education Skills and Training Deprivation, Barriers to Housing and Services, Living Environment Deprivation, and Crime. Data were explored for overall area deprivation as a combined measure of local socio-economic stressors to which OSEI, as an adaptive response, ought to exhibit sensitivity. OSEI type localities were subsequently evaluated for variance across the sub-domains health deprivation and crime and disorder deprivation for each LSOA in the study area. These two sub-domains were chosen given their salience in previous studies into the benefits of user participation in urban green space (Kaplan 1995; Jackson 2003; Maas et al. 2006; Maller et al. 2006; Gidl f-Gunnarsson and hrstr $\mathrm{m}$ 2007). Such work has highlighted that proximity to, and interaction with, nearby nature can be an effective buffer against both poor health (de Vries et al. 2003; Mitchell and Popham 2007) and crime levels (Kuo et al. 1998; Kuo and Sullivan 2001) in urban areas. Accordingly, it was hypothesised that OSEI, if capable of adapting to unique social-ecological conditions, should exhibit unique responses to such conditions.

A rationale was developed to test the occurrence of OSEI as exhibiting adaptive capacity based on the three criteria obtained from the literature review. To investigate the emergence of OSEI as a coherent adaptive response (criterion $a$ ) the locations of examples of OSEI were explored for evidence of social and environmental deprivation relative to the remainder of the study area. This was achieved by carrying out a comparison of mean surface sealing (independent samples t-test) and mean IMD score (Mann-Whitney U-test), as a reflection of overall socio-economic deprivation, between areas with and without evidence of OSEI. Given that social-ecological innovation is the result of urban resident participation, statistical tests between OSEI locations and the remainder of the study area (Mann-Whitney U-test) were also carried out to explore whether local population density was a significant factor in the emergence of the phenomenon.

The diversity of responses inherent in OSEI (criterion $b$ ) was explored through the mapping of examples of OSEI and establishing a typology of OSEIs based on the management style and horticultural activities taking place at each site.

To investigate the distribution of types of OSEI as demonstrating adaptation to local environmental conditions (criterion $c$ ), univariate analyses of variance were subsequently performed to assess the influence of area characteristics on the distribution of different types of OSEI. Discriminant function analysis was subsequently employed to evaluate the characterisation of OSEI types. The same land-cover (Generalised Land Use Database) and socioeconomic (IMD) datasets were employed here as for the investigation of criterion $a$. This approach to characterising OSEI types according to physical and socio-economic environmental factors was based on the assumption that discrete types of OSEI, if they are to be considered adaptive, would constitute coherent responses to unique social-ecological conditions. 


\section{Results}

The study area is presented in Fig. 1. Internal boundary lines demark LSOAs which are categorised according to surface sealing extent. A total of 113 examples of OSEI were identified. The spatial distribution of those OSEIs recorded is shown overlaid.

\section{Environmental contexts of OSEI}

Comparing surface sealing extent in OSEI localities (mean $=47 \% \pm 17 \%$ ) against the rest of the study area (mean $=41 \% \pm 16 \%$ ) revealed a highly significant mean difference $(\mathrm{t}(539)=-3.092 ; p=0.002)$. The data presented OSEIs as being in locations which, on average, contained a minority of green space versus hard-standing surfaces (with $66 \%$ of OSEIs occurring in areas with lower than $50 \%$ green space cover), whereas, for the study area in general, the reverse was true.

Analysis of mean Index of Multiple Deprivation scores for LSOAs containing OSEI $($ mean $=39.03 \pm 17.06)$ against those without (mean $=32.56 \pm 19.84)$ demonstrated a highly significant level of variance ( $p=0.004)$ indicating that on the whole OSEI occurred in areas that were subject to higher than average levels of deprivation for the study area. Comparing 2010 IMD data with that from 2004 allowed for an analysis of area improvement according to increase or decrease in IMD score. These data demonstrated that the non-OSEI locations had improved between 2004 and 2010 (mean IMD change $=-3.62 \pm 33.19$ ) but that localities of OSEIs (Group 1) exhibited a far greater mean improvement (mean change $=-15.73 \pm 28.01$; $p=0.002$ ). This indicated that OSEIs had been occurring in areas that were improving, in deprivation terms, at a rate over $300 \%$ greater than the study area as a whole. Comparing mean population density (persons per hectare) by LSOA for areas containing OSEI against those without, revealed that the localities of OSEIs bore a higher mean figure (mean $=55 ; \pm 35$ ) than the rest of the study area (mean $=52 ; \pm 31)$, but not at a significant level $(p=0.902)$.

Following the initial mapping exercise, a typology was established with examples of OSEI in the study area being categorised based on site management and overall social-ecological remit. The typology defined OSEIs as belonging to one of five categories:

\section{Community gardens}

Although the two terms "allotment gardens" and "community gardens" are often used synonymously and interpreted liberally, for the purpose of this work "community garden" will be used distinctly to refer to areas of public green space which are maintained by members of the community for a range of activities and social provision, a proportion of which is often centred around gardening for food but with a range of additional structures facilities which serve priorities such as leisure and educational activities, social interaction, and provision of communal open spaces.

\section{Community allotments}

These sites were pre-existing or adapted plots on established allotment gardens which had been designated by the local council as areas for use by the wider community primarily for food 


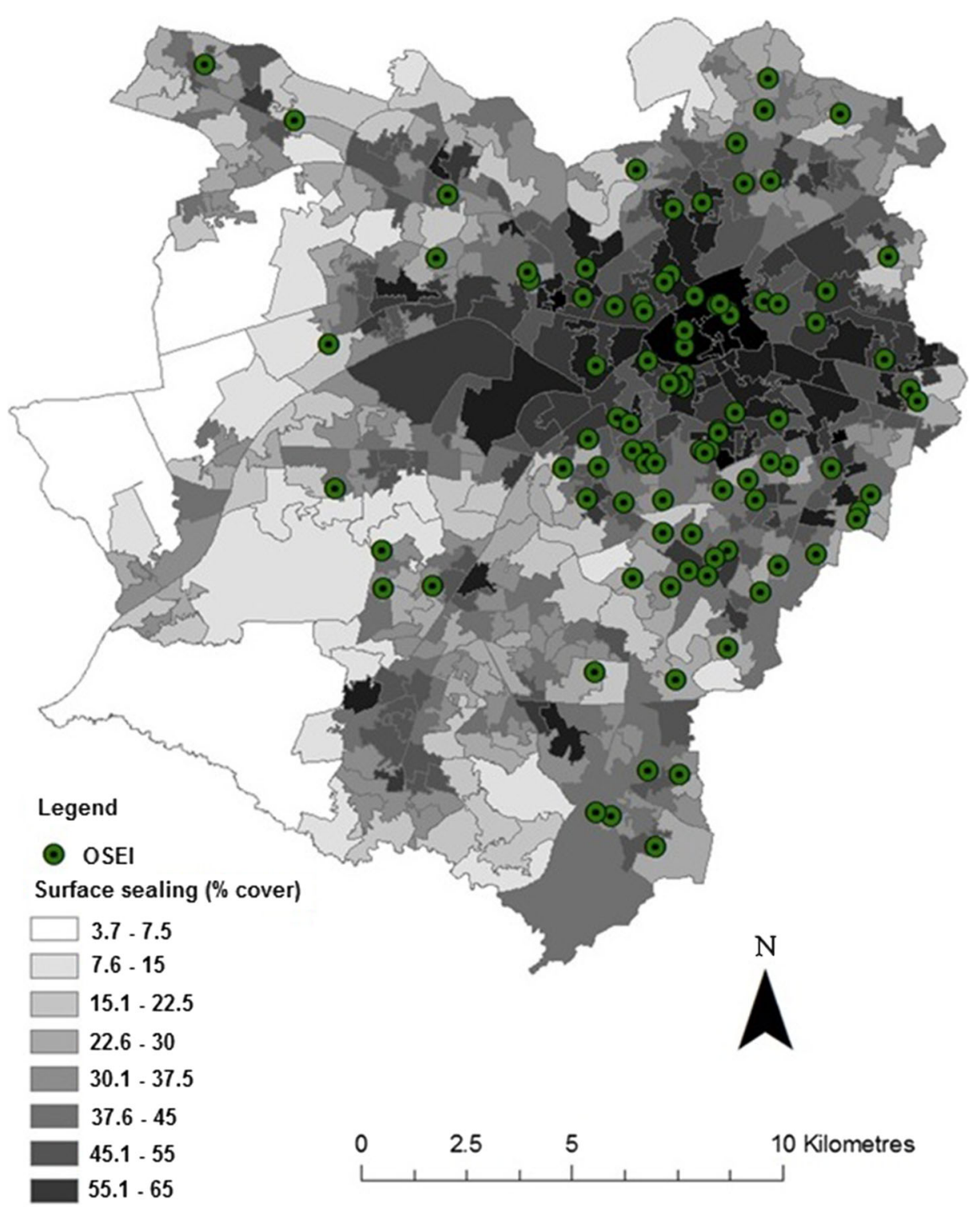

65.1 - 75

75.1 - 91

Fig. 1 Distribution of OSEI and surface sealing extent (of LSOAs) in the study area (ONS 2001, 2005)

production and related educational activities. Of all types, community allotments and gardens were those which exhibited greatest similarity. However, in the majority of cases community allotments were identified as such either by signage or in other forms of publicity (e.g. internet presence). In cases where classification was not clear or self-designated, sites were allocated to the community allotment type where food production was judged to be the primary design feature. 


\section{Community orchards}

Community orchards within the thesis are defined as areas of land managed by local residents and volunteers which are dedicated primarily to the cultivation of hard and soft fruits. Features of site structure and management may overlap with those of the other three categories of social-ecological innovation as defined herein but the defining characteristic is the overarching emphasis of the production of fruit whether through traditional or modern techniques.

\section{Pocket parks}

Pocket parks were those sites which, usually as a result of their location, exhibited the most highly improvised approach to urban greening. They are defined as sites which occur in areas of high surface sealing and as such achieve their impact by maximising the use of available top soil and using an innovative array of container planting and other improvised naturalistic features such as green roofs and walls. This OSEI type was easily distinguishable from others by the surrounding and pre-existing land-use. Sites occurred on pockets of land subject to high or complete surface sealing and, subsequently, were often much smaller than sites of other types. Sites falling in the pocket park category, by virtue of their highly urbanised locations did not exhibit total areas greater than $250 \mathrm{~m}^{2}$.

\section{Environmental resource projects}

The remaining sites formed a category of innovation which were not primarily land-based but which consisted of premises or mobile projects which served as hubs of environmental information, training or resources. Often such groups were actively involved in the promotion of socialecological innovation and/or urban agriculture and in the forming of social networks between groups. Some of these sites also exhibited small-scale therapeutic or educational horticultural activities as a secondary service or as satellite projects. Some projects were, however purely "office-based" and, in some cases, multiple projects were housed in the same building.

The land-based types (1-4) represent horticultural approaches to OSEI and were primarily involved in land management and, in a majority of cases, food production. Accordingly, these types collectively consist of a provisioning approach to OSEI and are able to provide direct and indirect use benefits. OSEIs which form the final group are principally devoted to providing resources, information, training and networking opportunities to groups and individuals involved in OSEI and related environmental activities. As such these constitute a supporting form of OSEI.

As sites were recorded and mapped they were placed into one of the above categories based on site characteristics. The results of this categorisation are presented in Table 1.

The most common form of organised social-ecological innovation was community gardens (35.4\%), followed by community allotments and environmental resource projects, each accounting for around twenty percent of the total.

\section{Contexts of OSEI according to type}

The analysis of the social-ecological context of OSEIs revealed that levels of social and environmental deprivation were both significant in the occurrence of OSEI. This subsequently 
Table 1 Site categories

\begin{tabular}{lll}
\hline OSEI type & Number & Percentage of total \\
\hline Community garden & 40 & 35.4 \\
Community allotment & 23 & 20.4 \\
Pocket park & 15 & 13.3 \\
Community orchard & 13 & 11.5 \\
Environmental resource project & 22 & 19.5 \\
Total & 113 & 100.0 \\
\hline
\end{tabular}

provided the basis for the analysis of the distribution of types of OSEI in the landscape. Boxplot analysis revealed that the data for IMD score and proportion surface sealing followed normal patterns of distribution across types of OSEI and were entered into one-way ANOVA for analysis.

The result of the ANOVA revealed a significant mean difference across the localities of the five types of OSEI for percentage surface sealing $(\mathrm{F}(4)=21.358 ; p<0.001)$. Post-hoc testing (LSD) for proportion surface sealing revealed that pocket parks (mean $=71 \% ; \pm 16 \%$ ) and environmental resource projects (mean $=66 \% ; \pm 10 \%$ ) were the most homogenous types, both scoring above the grand mean of $51 \%$ and differing significantly from the other three OSEI types at the $p<0.05$ level. The biggest significant mean difference observed was $33 \%(p<0.001)$ between community allotments and pocket park locales. The means plot and a table summarising significant between-group mean differences are presented in Fig. 2 and Table 2.

Significant mean differences in surface sealing were observed between pocket park locations and that of all other types with the exception of environmental resource projects. These two types thereby comprised the most homogenous types. All significant differences are summarised in Table 2.

Although significant differences were not found for overall IMD score $(F(4)=1.455$; $p=0.221)$, discrepancies were observed across two of the IMD domains: Health Deprivation $(\mathrm{F}(4)=2.606 ; p=0.40)$ and Crime and Disorder $(\mathrm{F}(4)=3.593 ; p=0.009)$. Means plots for the two domains are presented in Figs. 3 and 4 (scores are dimensionless) with significant between-group mean differences revealed by post-hoc tests (LSD) summarised in Tables 3 and 4.

Post-hoc tests (LSD) for type mean health deprivation scores revealed two significant mean differences as summarised in Table 3.

The means plot for type crime and disorder scores demonstrated a markedly different distribution than for health deprivation (Fig. 4).

Post-hoc tests across crime and disorder deprivation scores revealed greater disparity between types than did health deprivation with four significant mean differences (Table 4).

Both physical (land-cover) and social (health and crime and disorder deprivation) appeared to delineate to some degree the discrete types of OSEI. To confirm this inference data on three land-cover density (\% cover) values for domestic gardens, surface sealing and buildings, three Index of Multiple Deprivation domain indices: Income, Health, and Crime and Disorder, as well as data on population density were entered into a discriminant function analysis. The first function of the discriminant analysis produced an eigenvalue of 1.14 and accounted for $73 \%$ of the variation between types, with a canonical correlation of 0.73 . Surface sealing, domestic garden cover and buildings density exhibited the highest correlations within the first function, 


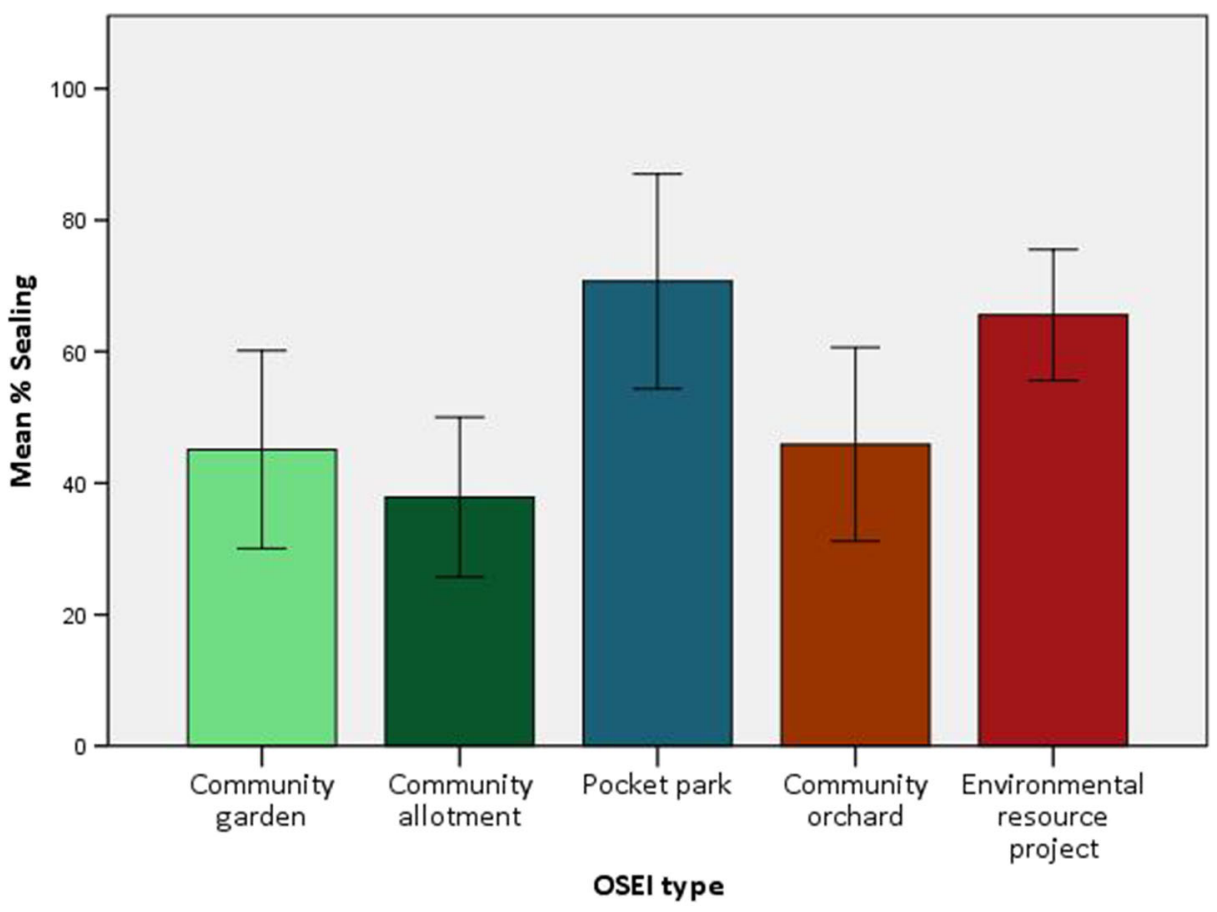

Error Bars: +/- 1 SD

Fig. 2 Means plot for ANOVA model: surface sealing (as percentage). Grand mean $=51 \% \pm 18 \%$

presenting physical characteristics as the most significant in classifying type locations. Crossvalidation analysis revealed that $52 \%$ of group cases were correctly classified, a $126 \%$ improvement on prior probability estimates, lending satisfactory credence to the model. The model's structure matrix is presented in Table 5.

\section{Dynamics of social-ecological deprivation}

The presentation of OSEI types in the means plots for surface sealing and IMD domain scores (Figs. 2, 3 and 4) suggested that environmental resource projects occurred in areas with the highest levels of combined social and environmental deprivation with mean values above those of the OSEI sample for both surface sealing and IMD domain variables. An appreciation of the mean degree of social-ecological deprivation extant in OSEI-type localities was enabled

Table 2 Significant mean differences between OSEI type locations: proportion surface sealing

\begin{tabular}{lllll}
\hline OSEI Type & Community Allotment & Pocket Park & Community Orchard & $\begin{array}{l}\text { Environmental Resource } \\
\text { Project }\end{array}$ \\
\hline Community Garden & $0.048^{*}$ & $<0.001^{* *}$ & 0.855 & $<0.001^{* *}$ \\
Community Allotment & & $<0.001^{* *}$ & 0.096 & $<0.001^{* *}$ \\
Pocket Park & & $<0.001^{* *}$ & 0.269 \\
Community Orchard & & & $<0.001^{* *}$
\end{tabular}

*Significant at $p<0.05$ level; ** significant at $p<0.001$ 


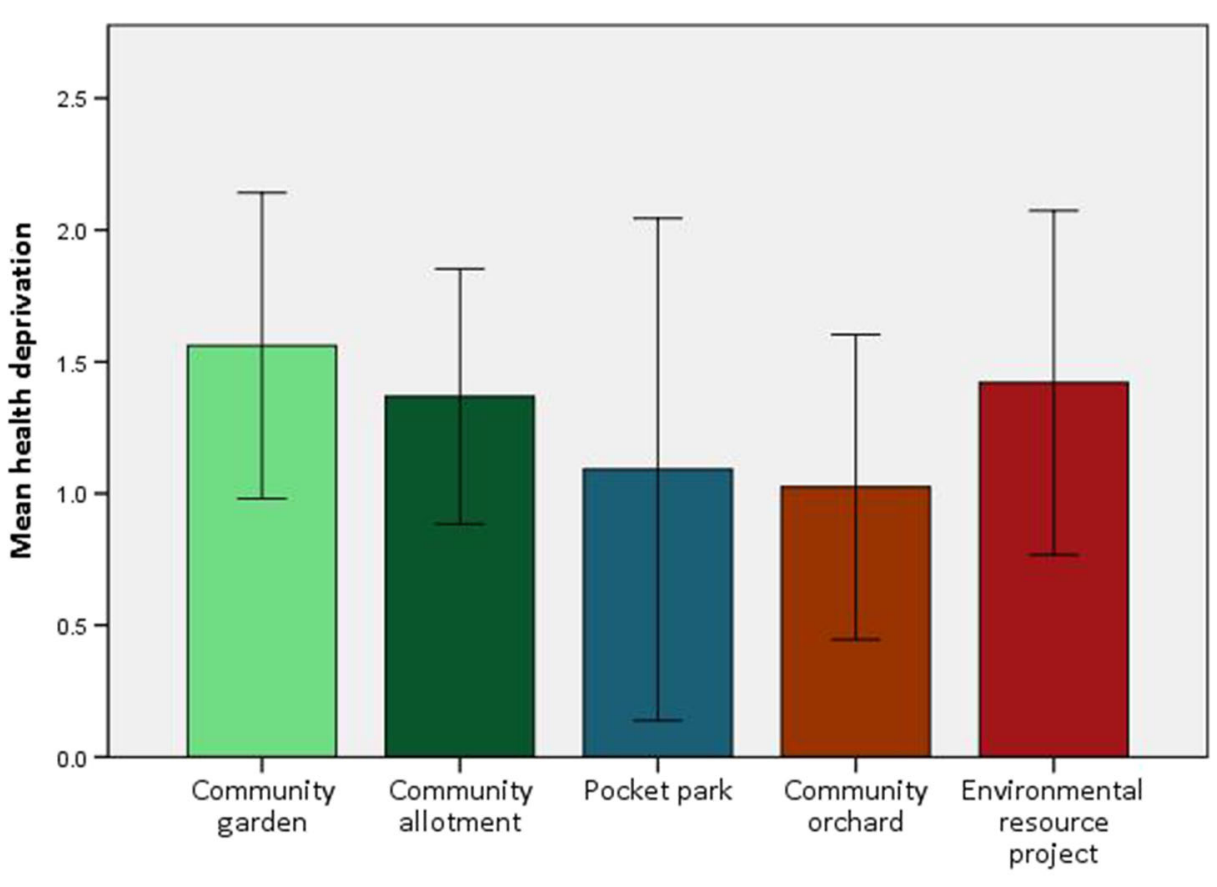

OSEI type

Error Bars: +/- $1 \mathrm{SD}$

Fig. 3 Type mean health deprivation scores. Grand mean $=1.37 \pm 0.66$

by plotting type means for surface sealing against that for IMD score which drew out the relative character of each. These are presented in Fig. 5 (with standard deviation error bars).

\section{Discussion}

Adaptive co-management, based on stakeholder-led ecosystem stewardship, has received increasing attention in the literature as a decentralised approach to natural resource management that could build resilience in urban social-ecological systems (Andersson et al. 2007; Biggs et al. 2010; Olsson and Galaz 2012; Krasny and Tidball 2012; Rodima-Taylor et al. 2012; Krasny and Tidball 2015). However, much of the work carried out into the emergence of social interventions in urban natural resource has taken an anthropological approach (see Krasny and Tidball 2015). Without a quantitative demonstration of the spatial distribution of community-managed spaces, and the diversity inherent in the management of those spaces relative to local environmental contexts, it has hitherto remained unclear whether such innovation builds on adaptive capacity.

The spatial analyses presented here of examples of OSEI throughout the study area revealed that there was a significant tendency for them to occur in areas of increased socio-economic and environmental deprivation. Additionally, the appearance of the phenomenon seemed to coincide with poor but greatly improving socio-economic conditions, suggesting that social capital may be instrumental in appearance of OSEI. The data, thereby, provide support to previous work which has highlighted the positive role of social capital in environmental 


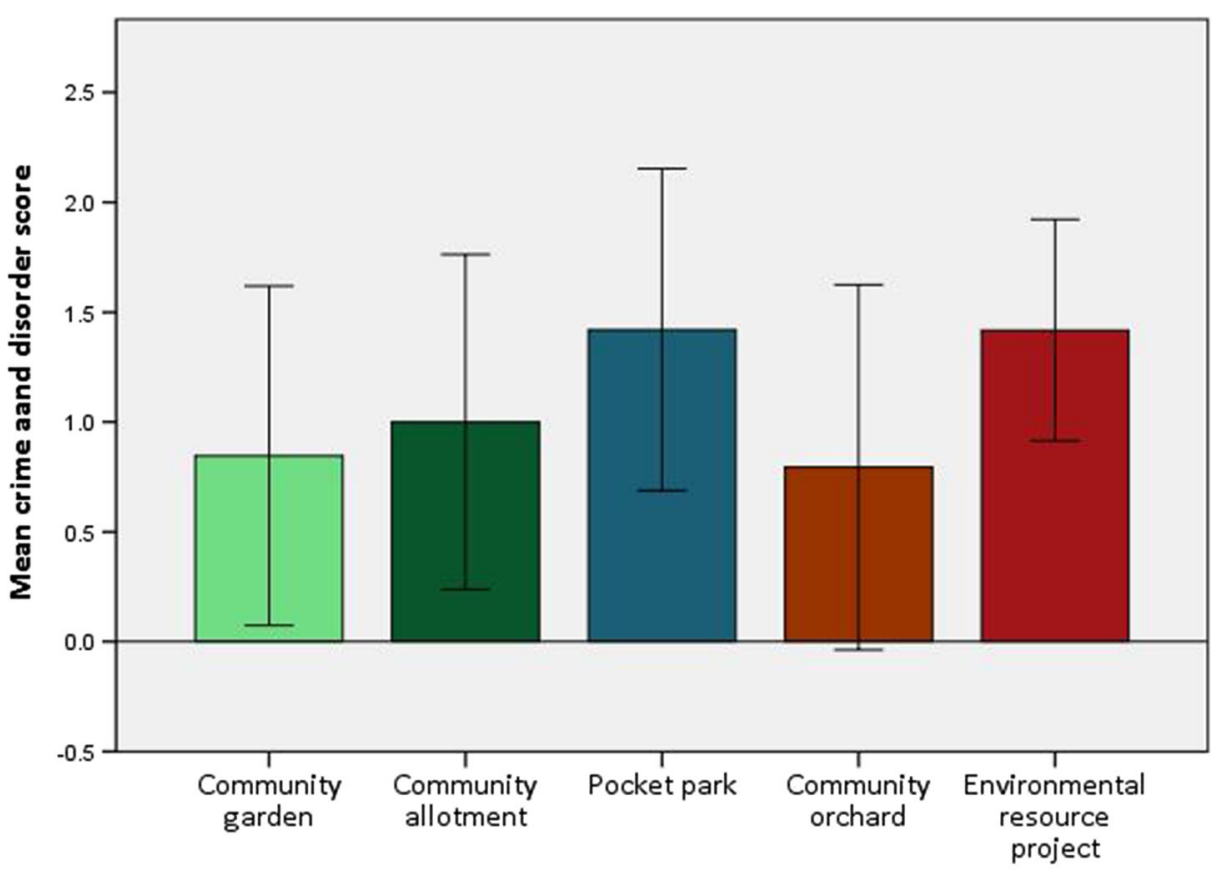

OSEI type

Error Bars: +/- 1 SD

Fig. 4 Type mean crime and disorder deprivation scores. Grand mean $=1.06 \pm 0.76$

stewardship (Selman and Parker 1997; Armitage et al. 2009; Ernstson et al. 2010). Although this does not prove categorically a causal effect between social-ecological conditions and innovation, the data nevertheless present the phenomenon as, due to its spatial distribution, fulfilling criterion $a$ : exhibiting responsivity to environmental conditions.

The exploration of OSEI throughout the study area resulted in the categorisation of five discrete types of OSEI according to site management and design, and horticultural activities. This exercise thereby provided evidence of response diversity (criterion $b$ ) in the occurrence of OSEI. The results of the ANOVA models offered support to both the validity of the typology and the uniqueness of OSEI types according to local contexts. These analyses presented surface sealing, as a proxy for environmental deprivation, as the most salient variable in terms of delineating types of organised social-ecological innovation. From the post-hoc analyses, this

Table 3 Significant mean differences between type locations: health deprivation

\begin{tabular}{lllll}
\hline OSEI Type & Community Allotment & Pocket Park & Community Orchard & $\begin{array}{l}\text { Environmental Resource } \\
\text { Project }\end{array}$ \\
\hline Community Garden & 0.25 & $0.017^{*}$ & $0.010^{*}$ & 0.407 \\
Community Allotment & & 0.193 & 0.123 & 0.784 \\
Pocket Park & & 0.783 & 0.126 \\
Community Orchard & & & 0.079
\end{tabular}

$*=$ Significant at $p<0.05$ level 
Table 4 Significant mean differences between type locations: crime and disorder

\begin{tabular}{lllll}
\hline OSEI Type & Community Allotment & Pocket Park & Community Orchard & $\begin{array}{l}\text { Environmental Resource } \\
\text { Project }\end{array}$ \\
\hline Community Garden & 0.421 & $0.010^{*}$ & 0.821 & $0.004^{* *}$ \\
Community Allotment & & 0.084 & 0.415 & 0.057 \\
Pocket Park & & $0.025^{*}$ & 0.990 \\
Community Orchard & & & $0.016^{*}$ \\
\hline
\end{tabular}

$*=$ Significant at $p<0.05$ level; ** significant at $p<0.01$

variable produced the greatest number of significant between-type mean differences (seven: Table 2) followed by the deprivation domains crime and disorder (four: Table 3) and health (two: Table 4), with overall IMD score proving not to be significant. A detailed analysis of the factors which contributed to the characterisation of OSEI types, through the discriminant function analysis (Table 5), added satisfactory confirmation of the relative effect of social and environmental elements in the landscape on the emergence of divergent types of OSEI. The model presented the land-cover variables surface sealing, buildings density and domestic gardens density as providing the most significant contribution to type characterisation. Again, of the socio-economic variables, crime and disorder deprivation was the most salient, with health and income deprivation proving to be weakly predictive and population density offering very little predictive power to the model. OSEI therefore, demonstrated evidence of adaptation to local socio-environmental niches though the sensitivity of such adaptation varied according to particular types of social, and environmental, deprivation. Specifically, OSEI exhibited adaptation (criterion $c$ ), to local levels of surface sealing, crime and disorder deprivation and, to a lesser degree, health deprivation. Given the reported benefits of stakeholder engagement in green space management to local biodiversity (Dennis and James 2016), ecosystem service provision (Barthel et al. 2010), health promotion (Hynes and Howe 2004; Alaimo et al. 2008; Pudup 2008; Metcalf and Widener 2011; Kazmierczak et al. 2013) reduced crime (Kuo et al. 1998; Kuo and Sullivan 2001), sense of place (Krasny and Tidball 2015) and community cohesion (Okvat and Zautra 2011), the adaptive nature of OSEI presents the phenomenon as one which should be given serious consideration as a vital ingredient to resilient social-ecological systems associated with urban areas.

Table 5 Discriminant function analysis: structure matrix

\begin{tabular}{|c|c|c|c|c|}
\hline & \multicolumn{4}{|l|}{ Function } \\
\hline & 1 & 2 & 3 & 4 \\
\hline Surface sealing & $0.806^{*}$ & 0.355 & 0.302 & -0.175 \\
\hline Gardens density & $-0.557^{*}$ & 0.239 & 0.409 & -0.469 \\
\hline Population density & -0.017 & $0.529^{*}$ & 0.182 & -0.378 \\
\hline Buildings density & 0.442 & 0.236 & $0.565^{*}$ & -0.208 \\
\hline Health deprivation & -0.138 & 0.399 & -0.093 & $0.850^{*}$ \\
\hline Income deprivation & -0.041 & 0.436 & -0.382 & $0.559^{*}$ \\
\hline Crime and disorder & 0.319 & 0.019 & -0.304 & $0.481^{*}$ \\
\hline
\end{tabular}

*Largest absolute correlation between each variable and any discriminant function 


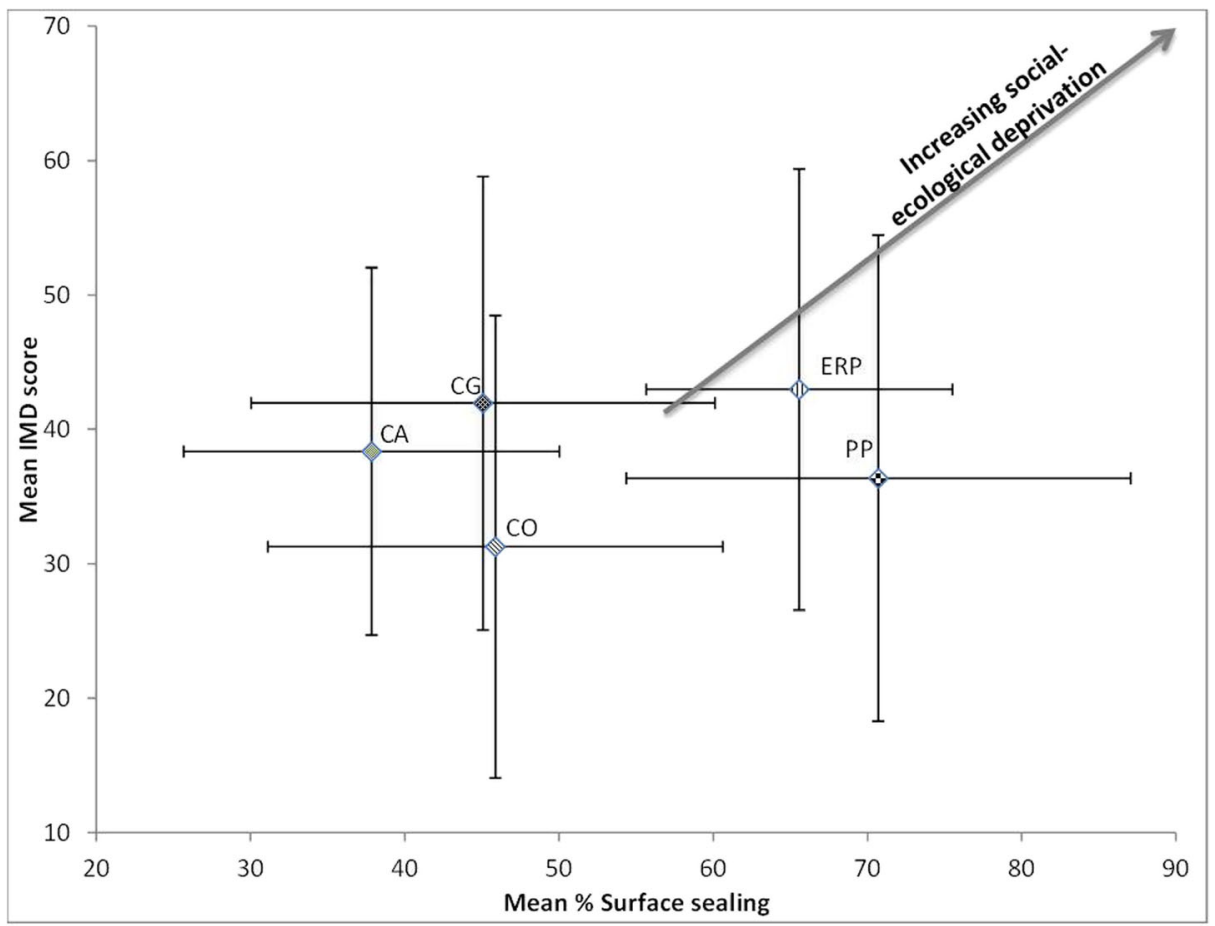

Key: $\mathrm{CG}=$ community garden; $\mathrm{CA}=$ community allotment; $\mathrm{PP}=$ pocket park; $\mathrm{CO}=$ community orchard; $\mathrm{ERP}=$ environmental resource project

Fig. 5 OSEI type and degree of combined social-ecological deprivation

Notwithstanding these insights into the impact of the levels of both social and environmental deprivation on the distribution of OSEI types in the study area, there existed also a complex dynamic between the two. The representation of the data in Fig. 5 served to illustrate that particular configurations of combined social and environmental deprivation more readily encouraged the presence of particular types of OSEI. At the extremes of social-ecological deprivation, environmental resource projects were more commonly found in areas of high social deprivation whereas locations subject to extreme ecological deprivation (i.e. surface sealing) were more likely to engender pocket parks as a form of OSEI (Fig. 5). Of these two, the locations which exhibited the greatest degree of equal levels of social and ecological deprivation were those in which environmental resource projects were found occurring. Being that such OSEIs were primarily examples of supporting as opposed to provisioning forms of OSEI, it is inferred that beyond a certain level of combined social and ecological deprivation, provisioning OSEI may be less likely to occur and a supporting version of the phenomenon more commonly found.

The most noticeable contrast between type localities was exhibited by those of pocket parks and community gardens. The latter occurred largely in areas with relatively abundant green space but with high levels of health deprivation whereas the former type was mapped primarily in areas exhibiting the opposite configuration (Figs. 3 and 4). Furthermore, within the social deprivation domains these two types exhibited inverse patterns of health, and crime deprivation. As exemplified in the observed dynamic between the social and ecological contexts of community gardens and pocket parks, it would seem that provisioning forms of OSEI can occur in areas subject to the highest 
levels of social or ecological deprivation providing that such deprivation is buffered to a certain degree by more favourable conditions in the other parameter. Depending on the balance between social and ecological deprivation in such contexts, OSEI may take different, adaptive forms.

\section{Diffusion and thresholds in organised Social-Ecological innovation}

The role of informal social-ecological actors in the urban fabric, particularly their potential importance in terms of urban resilience, is a consideration which, although alluded to in the literature (Dietz 2003; Cash et al. 2006; Bodin and Crona 2009; Barthel et al. 2010; Colding et al. 2013), has not as yet been delineated in terms of the spatial dimension of its nascence and the social-ecological thresholds which shape its expression in the landscape. The appearance of OSEI in the study area was conditioned by social-ecological factors, the influence of which involved the presence of particular thresholds. The occurrence of OSEI seemed to accompany a minimum of combined social-ecological deprivation, as a lower threshold, after which different configurations of social and ecological conditions resulting in discrete types of OSEI until an upper threshold of deprivation was reached (Fig. 5). This relationship was not linear. The data in Fig. 5 demonstrate that, at the lower threshold, a certain degree of deprivation increased the likelihood of OSEI occurring. However, the same data revealed that, when relatively high levels of ecological deprivation in a given area were buffered by more favourable social conditions, and vice-versa, then OSEI appeared less likely to occur. Therefore, relatively lower levels of social and ecological deprivation, when found co-occurring, were more likely to provide a context for OSEI. This effect was mirrored at the upper threshold of social-ecological deprivation, where, once a certain combined level was reached, the occurrence of OSEI appeared to be significantly hindered. Again, as seen at the lower limits of deprivation, the buffering of high levels in one factor by relatively lower levels in the other affected the limits of this threshold. Here, relatively lower but equal degrees of combined social and ecological deprivation had a more deleterious effect on the emergence of OSEI than did a situation where higher levels of deprivation in either social or ecological conditions were mitigated by low levels in the other component factor. This tendency is summarised in Fig. 6, which is an annotated version of the scatter plot of mean social-ecological deprivation of type locations presented in Fig. 5. Lower and upper thresholds are denoted in Fig. 6 as well as a third threshold of combined social and ecological deprivation above which, supporting versions of OSEI appeared more common.

The upper and lower "thresholds" presented in Fig. 6 represent social-ecological boundaries which, if OSEI is to be incorporated into the management of resilience in social-ecological systems, may represent important tipping points affecting socially mediated adaptive capacity in social-ecological systems (Folke 2006; Kinzig et al. 2006; Walker et al. 2006; Walker et al. 2009). By learning from the presence of such tipping points, environmental managers and decision makers should be able to monitor and increase resilience at the local and landscape scale. This could be achieved by providing, in collaboration with local actors groups, appropriate social and environmental resources to buffer against the transgression of important social-ecological boundaries after which innovation and community-led stewardship of local natural resources may become jeopardised. The means by which this may be achieved would, however, require careful consideration to ensure that the diversity and innovation inherent in OSEI are allowed to continue. Further research would be necessary to unpick the potential trade-offs implied in the intervention of top-down organisations towards stimulating innovation in the landscape. 


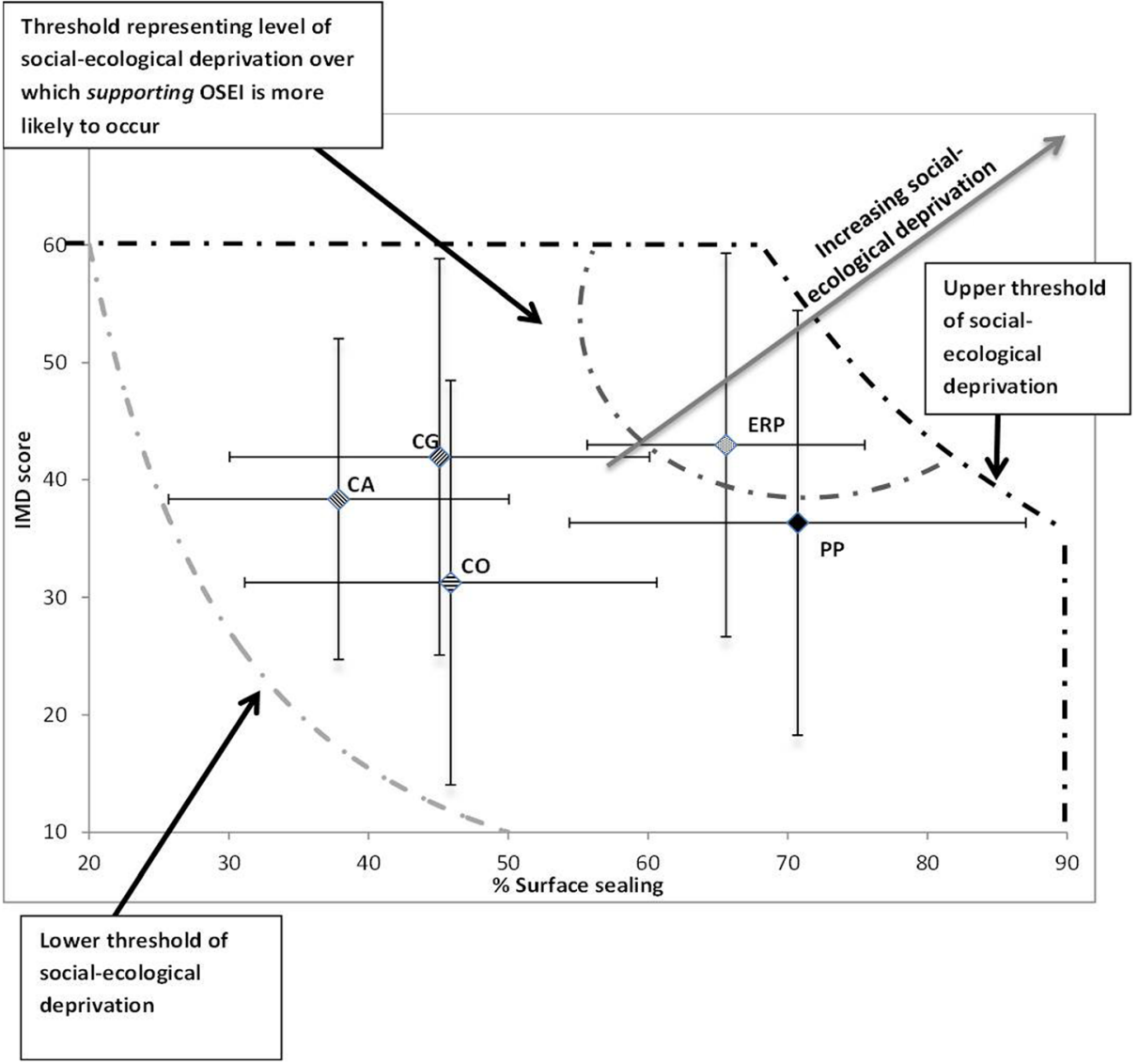

Key: $\mathrm{CG}=$ Community garden; $\mathrm{CA}=$ Community allotment; PP = Pocket park;

$\mathrm{CO}=$ Community Orchard $; \mathrm{ERP}=$ Environmental resource project

Fig. 6 Thresholds in the occurrence of OSEI

\section{Conclusions}

Organised social-ecological innovation exhibited an extensive presence in the urban landscape. That its occurrence was associated with social and ecological forms of deprivation, and that such innovation found niches according to local social-ecological conditions presents OSEI as a legitimate form of adaptive capacity in urban areas. Ecological factors were the most salient in shaping the physical form of OSEI, but the interaction between social and ecological factors were pivotal in determining the environmental thresholds within which OSEI occurred, and in what form. The study provided compelling evidence of OSEI as an adaptive form of local environmental stewardship by stakeholders which ought to be given serious consideration as an ingredient in urban environmental resilience. The work also outlined the presence of tipping points created by local social-ecological conditions which, if effectively managed, could encourage community generated adaptive capacity in urban areas. Future research into social-ecological networks associated with community-led natural resource management may provide greater detail as to the importance of social ties, actors and knowledge groups for the diffusion of social-ecological innovation. 
Open Access This article is distributed under the terms of the Creative Commons Attribution 4.0 International License (http://creativecommons.org/licenses/by/4.0/), which permits unrestricted use, distribution, and reproduction in any medium, provided you give appropriate credit to the original author(s) and the source, provide a link to the Creative Commons license, and indicate if changes were made.

\section{References}

AfSL (Action for Sustainable Living) n.d.. Funders - See who funds our work and projects. [online] Available at: http://www.afsl.org.uk/about/funders/ (accessed 15 Jan. 2015).

Alaimo K, Packnett E, Miles RA, Kruger DJ (2008) Fruit and vegetable intake among Urban Community Gardeners. Journal of Nutrition, Education and Behavior. 40(2):94-101

Andersson E, Barthel S, Ahrné K (2007) Measuring social-ecological dynamics behind the generation of ecosystem services. Ecological Applications. 17(5):1267-1278

Armitage D, Plummer R, Berkes F, Arthur R, Charles A, Davidson-Hunt I, Diduck A, Doubleday N, Johnson D, Marschke M, McConney P, Pinkerton E, Wollenberg E (2009) Adaptive co-management for socialecological complexity. Front Ecol Environ 7(2):95-102

Barthel S, Folke C, Colding J (2010) Social-Ecological memory in urban gardens: retaining the capacity for management of ecosystem services. Global Environmental Change. 20(2):255-265

Barthel S, Parker J, Ernstson H (2013) Food and green space in cities: A resilience lens on gardens and Urban Environmental Movements. Urban Studies. doi:10.1177/0042098012472744

Becker G, Mohren R (1990) The biotope area factor as an ecological phenomenon. Landschaft Planen and Bauen, Berlin

Biggs, R., Westley F., R. and Carpenter, S. R. 2010. Navigating the Back Loop: Fostering Social Innovation and Transformation in Ecosystem Management. Ecology and Society. 15(2): 9. [online] Available at: http://www. ecologyandsociety.org/vol15/iss2/art9

Biggs R, Schlüter M, Biggs D, Bohensky EL, BurnSilver S, Cundill G, Dakos V, Daw TM, Evans LS, Kotschy K, Leitch AM, Meek C, Quinlan A, Raudsepp-Hearne C, Robards MD, Schoon ML, Schultz L, West PC (2012) Toward principles for enhancing the resilience of Ecosystem Services. Annu Rev Environ Resour 37:421-448

Bodin Ö, Crona B (2009) The role of social networks in natural resource governance: what relational patterns make a difference? Global Environmental Change. 19(3):366-374

Breuste J, Qureshi S, Li J (2013) Applied urban ecology for sustainable urban environment. Urban Ecosystems 16(4):675-680

Brooks N, Adger N (2004) Assessing and enhancing Adaptive capacity. In: Lim B, Spanger-Siegfried E (eds) Adaptation Policy Frameworks for Climate Change: Developing Strategies, Policies and Measures, $1 \mathrm{st}$ ed. pp.165-181. Cambridge. Cambridge University Press

Carpenter, S. and Brock, W. 2008. Adaptive capacity and traps. Ecology and Society 13(2): 40. [online] Available at: http://www.ecologyandsociety.org/vol13/iss2/art40/

Cash, D. W., Adger, W., Berkes, F., Garden, P., Lebel, L., Olsson, P., Pritchard, L. and Young, O. 2006. Scale and cross-scale dynamics: governance and information in a multilevel world. Ecology and Society 11(2): 8. [online] Available at: http://www.ecologyandsociety.org/vol11/iss2/art8.

CBD (Convention on Biological Diversity). 2004 The Ecosystem Approach, (CBD Guidelines). Montreal. Secretariat of the Convention on Biological Diversity

CBD (Convention on Biological Diversity) (2012) Cities and biodiversity outlook. Montreal, Secretariat of the Convention on Biological Diversity

Colding J, Barthel S (2013) The potential of 'Urban Green Commons' in the resilience building of cities. Ecological Economics. 86:156-166

Colding J, Barthel S, Bendt P, Snep R, van der Knaap W, Ernstson H (2013) Urban green commons: insights on urban common property systems. Global Environmental Change. 23(5):1039-1051

Corrigan M (2011) Growing what you eat: developing community gardens in Baltimore, Maryland. Applied Geography. 31(4):1232-1241

DCLG (Department for Communities and Local Government). 2010. English Indices of Deprivation 2010 [computer file]. Downloaded from: https://www.gov.uk/government/statistics/english-indices-of-deprivation-2010. Licensed under: https:/www.nationalarchives.gov.uk/doc/open-government-licence/version/3

de Vries S, Verheij RA, Groenewegen PP, Spreeuenberg P (2003) Natural environments - healthy environments? An exploratory analysis of the relationship between greenspace and health. Environment and Planning. 35: $1717-1731$

Dennis M, James P (2016) User participation in urban green commons: exploring the links between access, voluntarism, biodiversity and well being. Urban Forestry \& Urban Greening. 15:22-31 
Dietz T (2003) The struggle to govern the commons. Science 302(5652):1907-1912

Elmqvist T, Folke C, Nyström M, Peterson G, Bengtsson J, Walker B, Norberg J (2003) Response diversity, ecosystem change, and resilience. Frontiers in Ecology and the Environment. 1(9): 488-494

Ernstson, H., Sörlin, S. and Elmqvist, T. 2008. Social movements and ecosystem services-the role of social network structure in protecting and managing urban green areas in Stockholm. Ecology and Society. 13(2): 39. [online] Available at: http://www.ecologyandsociety.org/vol13/iss2/art39/

Ernstson, H., Barthel, S., Andersson, E. and Borgstr m, S. 2010. Scale-Crossing Brokers and Network Governance of Urban Ecosystem Services: The Case of Stockholm. Ecology and Society. 15(4): 28. [online] Available at: http://www.ecologyandsociety.org/vol15/iss4/art28/

Folke C (2006) Resilience: the emergence of a perspective for social-ecological systems analyses. Global Environmental Change. 16(3):253-267

Folke C, Carpenter S, Elmqvist T, Gunderson L, Holling C, Walker B (2002) Resilience and sustainable development: building Adaptive capacity in a world of transformations. AMBIO: A Journal of the Human Environment 31(5):437-440

Folke C, Hahn T, Olsson P, Norberg (2005) Adaptive governance of Social-Ecological Systems. Annual Review of Environment and Resources. 30(1):441-473

Fuller R, Irvine K, Devine-Wright P, Warren P, Gaston K (2007) Psychological benefits of greenspace increase with biodiversity. Biology Letters. 3(4):390-394

Gidl f-Gunnarsson A, hrstr $\mathrm{m}$ E (2007) Noise and well-being in urban residential environments: the potential role of perceived availability to nearby green areas. Landscape and Urban Planning. 83:115-126

Goodman L (1961) Snowball sampling. Annals of Mathematical Statistics. 32(1):148-170

Green, G. and Phillips, R. 2013. Local food and community development. London. Routledge.

Gunderson L (2000) Ecological resilience: in theory and application. Annual Review of Ecology and Systematics. $31: 425-439$

Gunderson, L. 2010. Ecological and human community resilience in response to natural disasters. Ecology and Society. 15(2): 18. [online] Available at: http://www.ecologyandsociety.org/vol15/ iss $2 / \operatorname{art} 18 /$

Gunderson L, Berkley J (2015) Practical resilience: building networks of Adaptive Management. In: Allen C, Garmestani A (eds) Adaptive Management of Social-Ecological Systems, 1st edn. Springer, Dordrecht, pp. 201-216

Gunderson, L. and Holling, C., S. eds. 2002. Panarchy: Understanding Transformations In Human And Natural Systems. Washington. Island Press.

Hynes H, Howe G (2004) Urban horticulture in the contemporary United States: personal and community benefits. Acta Horticulturae 643:171-181. doi:10.17660/ActaHortic.2004.643.21

Jackson L (2003) The relationship of urban design to human health and condition. Landscape and Urban Planning. 64(4):191-200

Kalnay E, Cai M (2003) Impact of urbanization and land-use change on climate. Nature 423(6939):528-531

Kaplan S (1995) The restorative benefits of nature: toward an integrative framework. Journal of Environmental Psychology. 15(3):169-182

Kazmierczak A, Connelly A, Sherriff G (2013) Growing Manchester programme final evaluation report. Manchester. University of Manchester

Kidd A (2006) Manchester: A History. Lancaster. Carnegie Publishing

Kingsley J, Townsend M, Henderson-Wilson C (2009) Cultivating health and wellbeing: members' perceptions of the health benefits of a port Melbourne community garden. Leisure Studies. 28(2):207-219

Kinzig, A. P., P. Ryan, M. Etienne, H. Allison, T. Elmqvist, and B. H. Walker. 2006. Resilience and regime shifts: assessing cascading effects. Ecology and Society 11(1): 20. [online] Available at: http://www. ecologyandsociety.org/vol11/iss1/art20/

Krasny M, Tidball K (2009) Community Gardens as contexts for science, stewardship, and civic action learning. Cities and the Environment 2(1):1-18

Krasny M, Tidball K (2012) Civic ecology: a pathway for earth stewardship in cities. Frontiers in Ecology and the Environment. 10(5):267-273

Krasny M, Tidball K (2015) Civic Ecology: Adaptation and Transformation from the Ground Up. MA. MIT Press, Cambridge

Kruuse, A. 2011. GRaBS Expert Paper 6: The Green Space Factor and the Green Points System. London. Town and Country Planning Association

Kuo F, Sullivan W (2001) Environment and crime in the inner city: does vegetation reduce crime? Environment and Behaviour. 33:343-367

Kuo, F. Bacaicoa, M. and Sullivan, W., C. 1998. Transforming inner-city landscapes: trees, sense of safety and preference. Environment and Behavior. 30(1): 28-59 
Lambin E, Meyfroidt P (2011) Global land use change, economic globalization, and the looming land scarcity. Proceedings of the. National Academy of Sciences 108(9):3465-3472

Larsen S, Foulkes M, Sorenson C, Thompson A (2010) Environmental learning and the social construction of an exurban landscape in Fremont County, Colorado. Geoforum 42(1):83-93

Lo C (1997) Application of LandSat TM data for quality of life assessment in an urban environment. Computers, Environment and Urban Systems. 21(3-4):259-276

Maas J, Verheij R, Groenewegen P, de Vries S, Spreeuwenberg P (2006) Green space, urbanity, and health: how strong is the relation? Journal of Epidemiology and Community Health. 60(7):587592

Maller C, Townsend M, Pryor A, Brown P (2006) Healthy nature, healthy people: 'contact with nature' as an upstream health promotion intervention for populations. Health Promotion International. 21(1):45-54

MEA (Millenium Ecosystem Assessment) (2005) Ecosystems and Human Well-being: Health Synthesis. Island Press, Washington D.C

Metcalf S, Widener M (2011) Growing Buffalo's capacity for local food. Applied Geography. 31(4):1242-1251

Mitchell R, Popham F (2007) Greenspace, urbanity and health: relationships in England. Journal of Epidemiology \&amp. Community Health. 61(8):681-683

NASA. 2015. Measuring Vegetation (NDVI \& EVI): Feature Articles. [online] Available at: http:// earthobservatory.nasa.gov/Features/MeasuringVegetation/measuring_vegetation_2.php [Accessed 22 Dec. 2015]

Okvat H, Zautra A (2011) Community gardening: a parsimonious path to individual, community, and environmental resilience. American Journal of Community Psychology. 47(3-4):374-3387

Olsson P, Galaz V (2012) Social-Ecological innovation and transformation. In: Nicholls A, Murdock A (eds) Social innovation: Blurring Boundaries to Reconfigure Markets. Hampshire, Palgrave Macmillan

Olsson, P., Gunderson, L., Carpenter, S., Ryan, P., Lebel, L., Folke, C., and Holling, C. 2006. Shooting the rapids: navigating transitions to adaptive governance of social-ecological systems. Ecology and Society. 11(1): 18. [online] Available at: http://www.ecologyandsociety.org/vol11/iss1/art18/

ONS (Office for National Statistics). 2001 Census: Digitised Boundary Data (England and Wales) [computer file]. UK Data Service Census Support. Downloaded from: http://edina.ac.uk/census. Licensed under the terms of the Open Government Licence [http://www.nationalarchives.gov.uk/doc/open-government-licence/ version/2]

ONS (Office for National Statistics). 2005. Generalised land use database statistics for England [computer file]. London. Downloaded from: http://data.gov.uk/dataset/land_use_statistics_generalised_land_use_database.

ONS (Office for National Statistics). 2015. Super Output Area (SOA) - ONS. [online] Available at: http://www. ons.gov.uk/ons/guide-method/geography/beginner-s-guide/census/super-output-areas-soas-/index.html [Accessed 8 Dec. 2015].

Pauleit S, Duhme F (2000) Assessing the environmental performance of land cover types for urban planning. Landscape and Urban Planning. 52(1):1-20

Pudup M (2008) It takes a garden: cultivating citizen-subjects in organized garden projects. Geoforum 39(3):1228-1240

Ritvo H (2010) The Dawn of Green: Manchester, Thirlmere and Modern Environmentalism. University of Chicago Press, Chicago

Rodima-Taylor D, Olwig M, Chhetri N (2012) Adaptation as innovation, innovation as adaptation: An institutional approach to climate change. Applied Geography. 33:107-111

Rosol M (2012) Community volunteering as neoliberal strategy? green space production in Berlin. Antipode 44(1):239-257

Selman P, Parker J (1997) Citizenship, civicness and social capital in local agenda 21. Local Environment. 2(2):171-184

Southampton City Council (2013) Open Space \& Green Infrastructure Background Paper. Southampton City Council, Southampton

Tidball K, Krasny M, Svendsen E, Campbell L, Helphand K (2010) Stewardship, learning, and memory in disaster resilience. Environmental Education Research. 16(5-6):591-609

United Nations, Department of Economic and Social Affairs (2007) World Urbanisation Prospects: 2007 Revision. New York, United Nations

UK NEA (United Kingdom National Ecosystem Assessment) (2011) UK National Ecosystem Assessment: Understanding nature's value to society. UK NEA, London

Verburg, P., van Berkel, D., Valbuena, D. and Willemen, L. 2010. Modelling the influence of land use and land cover change on landscape functions. In: $L A N D M O D$. Montpellier: Symposcience, pp.1-3

Walker, B., Carpenter, J., Anderies, N., Abel, G., Cumming, M., Janssen, L., Lebel, J., Norberg, G., Peterson, D. and Pritchard, R. 2002. Resilience management in social-ecological systems: a working hypothesis for a participatory approach. Conservation Ecology 6(1): 14. [online] Available at: http://www.consecol.org/vol6/ iss1/art14/ 
Walker, B., Holling, C., Carpenter, S. and Kinzig, A. 2004. Resilience, adaptability, and transformability. Ecology and Society 9(2): 5. [online] Available at: http://www.ecologyandsociety.org/vol9/iss2/art5/.

Walker, B., Gunderson, L., Kinzig, A., Folke, C., Carpenter, S. and Schultz, L. 2006. A handful of heuristics and some propositions for understanding resilience in social-ecological systems. Ecology and Society 11(1): 13. [online] Available at: http://www.ecologyandsociety.org/vol11/ iss 1/art13/

Walker, B. N. Abel, J. Anderies, and Ryan, P. 2009. Resilience, adaptability, and transformability in the Goulburn-Broken Catchment, Australia. Ecology and Society 14(1): 12. [online] Available at: http://www. ecologyandsociety.org/vol14/iss1/art12/ 